and each will contain its own title page, page numbering and index.

\section{Science Masters' Association : Annual Meeting}

TrEe annual meeting of the Science Masters' Association will be held in the Royal College of Science, Imperial Institute Road, South Kensington, London, S.W.7, during December 28-30, the annual business meeting of the Association being on the last day. The president this year is Sir Edward Salisbury, director of the Royal Botanic Gardens, Kew, and he will deliver his prosidential address in the Courtauld Hall, Queen Elizabeth College, on the evening of December 28, his subject being "Science and Education". Two special discussions will be held : one on December 30 at which science teaching in secondary modern schools will be considered; and one on December 31 on first-year failures in the universities, which will be introduced by Dr. E. R. Roberts, of the Department of Inorganic Chemistry, Royal College of Science, and by Prof. F. A. Vick, of the Department of Physics, University College of North Staffordshire. On the morning of December 29 a lecture-demonstration of experiments with radioactive isotopes suitable for schools will be given by the members of the Radioactivity Sub. committee of the Association, and in the afternoon there will be a demonstration of ciné and cinémicrography in the teaching of natural history, given by K. A. Murch, of the Chichester High School for Boys. In the afternoon of December 30 the Science and Religion Group of the Association will hold a discussion, and in the evening Mr. T. D. Bourdillon, a member of the 1953 Everest Expedition, will lecture on the successful conquest of Mount Everest and on the use of oxygen during the $\operatorname{climb}$, which was his special responsibility. As in the past, manufacturers and publishers who advertise in the School Science Review will exhibit at the meeting, and the usual exhibition by members of apparatus and teaching aids which they have found useful will also be held. In addition, special displays will be given in the Royal College of Science by the Civil Defence Department of the Home Office, and in Queen Elizabeth College by members of the Science Departments there. Further information can be obtained from the annual meeting secretary of the Association, W. H. Dowland, 93 Westbourne Road, West Hartlepool, Co. Durham.

\section{British Institute of Radiology: Annual Congress}

THe annual congress and exhibition of the British Institute of Radiology will be held in Caxton Hall, Victoria Street, Westminster, London, S.W.I, during December 8-9. On the morning of the first day, an opening address will be given by Sir John Cockeroft, director of the Atomic Fnergy Research Establishment, on the future role of atomic energy in industry, science and medicine, and this will be followed in the afternoon by a symposium on the hazards from the increasing use of ionizing radiations, at which three papers will be read. In the evening Dr. Gwen Hilton (University College Hospital, London) will deliver the Mackenzie Davidson Memorial Lecture and will speak on the role of radioiodine in the treatment of car cinoma of the thyroid. The second day will be devoted to papers on the clinical applications of image intensification, and three symposia as follows : pulmonary fibrosis and collagen diseases of the lungs; the influence of histological structure on radiosensitivity ; the introduction of the rad in radiotherapy practice.
The fee for the congress is 1 guinea (10s. 6d. for members of the Institute). Further information can be obtained from the Honorary Secretary of the Institute at 32 Welbeck Street, London, W.1.

\section{Christmas Lectures for School Children}

A Christmas lecture for older school children, arranged by the Institution of Electrical Engineers, will be given at the Institution (Savoy Place, London, W.C.2) on December 29 at 3 p.m., and again on the following day, by Mr. R. Brooks, his subject being "Electric Traction". The lecture will outline the principal features and methods of operation of the different systems of electric traction now in use, particular reference being made to the oquipment of the locomotives and motor coaches used on main. line and suburban services. The main principles of electric railway signalling will also be considered, together with a demonstration of full-size apparatus including searchlight-type signals. Admission to the lecture is free, and application for tickets, stating for which afternoon they are required, should be made to the Secretary of the Institution at the above address. The Royal Institution's Christmas lectures this year will be the 126th such "Course of six lectures adapted to a Juvenile Auditory". The course will be given by Prof. H. W. Melville at 3 p.m. on December 27, 29 and 31 and January 3, 5 and 7, his subject being "Big Molecules". The topics to be discussed at the six lectures will be, respectively, the making of big molecules, the size of a big molecule, rubber and the rubber-like state, man-made fibres, and plastics from big molecules (two lectures). For non-members of the Royal Institution, the fees for the course are: children (10-17 years) $£ 1$, adults £2. Application for tickets should be made to the Royal Institution, 21 Albemarlo Street, London, W.1.

\section{Announcements}

Sir Georar Lloyd-JACOB, one of Her Majesty's Judges of the High Court of Justice, has accepted appointment as a Trustee of the Ciba Foundation for the Promotion of International Co-operation in Medical and Chemical Research.

The University of Sheffield has conferred the title of emeritus professor of engineering on Prof. $\mathrm{H}$. W. Swift, and that of emeritus professor of glass technology on Prof. H. Moore, both of whom have recently retired from their respective chairs.

THE Department of Scientific and Industrial Research has appointed Sir Walter Drummond, formerly chairman of the National Coal Board, and Prof. N. F. Mott, Cavendish professor of physics in the University of Cambridge, to bo the Department's visitors to the Electrical Research Association, in succession to Dr. P. Dunsheath and Prof. J. T. Randall, whose period of service has been completed.

Tre Mond Nickel Co., Ltd, has appointed Dr. G. L. J. Bailey to bo superintendent of its Platinum Metals Research Laboratory at Acton, London, N.W.10, in succession to Dr. E. C. Rhodes. Dr. Bailey, who is a graduate of the Imperial College of Science and Technology, London, was on the staff of the Admiralty Engineering Laboratory, West Dray. ton, throughout the Second World War, and since 1945 he has been a member of the British NonFerrous Metals Research Association, where he is at present deputy research manager. 